\title{
BIOSECURITY APPROACHES TO SURVEILLANCE AND RESPONSE FOR NEW PLANT PEST SPECIES
}

\author{
B.P. STEPHENSON, G.S.C. GILL, J.L. RANDALL and J.A. WILSON
}

\author{
MAF Biosecurity Authority, Plants Biosecurity, P. O. Box 2526, Wellington \\ Corresponding author: StephensonB@maf.govt.nz
}

\begin{abstract}
There is a wide variety of organisms associated with plants and plant products. A number of offshore and border measures are taken to exclude such organisms not present in New Zealand, but some enter undetected. Surveillance throughout New Zealand to achieve early detection and effective eradication programmes for all potential pest species is logistically not feasible and can realistically only be undertaken for targeted pests. The National Plant Pest Reference Laboratory (NPPRL) conducts general surveillance activities but this usually only detects pests once they have established and dispersed in New Zealand. The Ministry of Agriculture and Forestry (MAF) is currently investigating the feasibility of conducting targeted surveillance to achieve eradication for significant pests other than fruit flies and sees this to be a critical area for industry involvement. Exclusion remains New Zealand's best defence against plant pests.
\end{abstract}

Keywords: biosecurity, MAF, incursion, surveillance, policy.

\section{INTRODUCTION}

The isolation of New Zealand and its natural barriers, such as climate, ocean and mountains, has meant that it is relatively free of pests. There is, however, a growing risk of incursions of harmful organisms with increasing volumes of traded goods and tourists arriving in New Zealand from diverse points of origin. The increased risk of incursion threatens this country's diverse primary production and unique flora and fauna. Increased pressures on our borders have led to the evolution of strategies and technologies for surveillance, detection and management of new organisms. The success of these strategies is important when considering that the Plants Biosecurity group of the Ministry of Agriculture and Forestry (MAF Plants Biosecurity) is faced with 20-30 detected incursions of new to New Zealand organisms per year.

The scope of MAF Plants Biosecurity's responsibilities currently covers plants used in agriculture and horticulture. This paper describes the existing components of MAF Plants Biosecurity's surveillance arrangements, and discusses the challenge of enhancing the system to enable detection of significant pests in time to eradicate.

\section{Fruit fly surveillance programme}

\section{EXISTING SURVEILLANCE ARRANGEMENTS}

The fruit fly trapping programme is the only active surveillance programme currently operated by MAF Plants Biosecurity. Surveillance traps for fruit fly have been in place since 1989 and are operated under contract. Traps are operated in main centres, around ports, international airports, in areas with high levels of tourist activity and in areas of horticultural significance. Traps are baited with attractants that lure adult fruit flies into contact with an insecticide. Three lures are used in a grid at various spacings to trap economically important fruit flies (Cowley 1990). The traps are monitored every two weeks during the spring, summer and autumn months and the current program costs approximately \$NZ1 million annually. There is a total of 2952 trap sites in the North Island (2107 in Auckland) and 506 sites in the South Island. 
The trapping programme successfully detected three Bactrocera passiflorae in Auckland in 1990, one B. tyroni in Whangarei in 1995, two B. tyroni in Auckland in 1996 and one B. papayae in Auckland in 1996. Further intensified surveillance for these species consisting of deploying additional traps at specified densities following fly detection produced no further finds, indicating that they were lone individuals unable to initiate populations, and they probably originated from single pieces of recently discarded smuggled fruit. Two Ceratitis capitata (Med fly) were detected in Auckland on 2 May 1996 and on this occasion intensified surveillance yielded further trap catches and detections of larvae in fruit. A successful eradication programme was implemented (Holder et al. 1997). X-ray machines were introduced for baggage examination at all New Zealand's international airports as a consequence of the 1996 Med fly outbreak, and there have been no further fruit fly detections since then.

Exotic pest response simulations are conducted at regular intervals so that staff can develop and maintain their skills and improve pre-defined response systems as required. Simulations train staff to act promptly and effectively when detections occur, and for fruit fly these arrangements are closely aligned with the surveillance programme.

\section{General surveillance}

The MAF National Plant Pest Reference Laboratory (NPPRL) is the key government agency involved in the identification of suspect exotic pests from general surveillance activities. General surveillance relies on submissions (either suspect samples or records of identifications from non-MAF scientists) from sources such as the public, research organisations and museums, and usually only detects pests once they have established and dispersed in New Zealand.

As well as general surveillance identifications, the NPPRL maintains records of new organisms, hosts, and distributions, and assists with the management of new pest incursions. Incursion activities include provision of pest identifications, provision of technical information and conduct of surveys. The NPPRL also identifies pests intercepted at the border, in post-entry quarantine and transitional facilities.

\section{Crop surveys}

Between 1989 and 1999, the NPPRL undertook surveys on one major crop or crop group per year (e.g. pipfruit, sub-tropicals, legumes, cereals) to establish the current pest status. Pests are defined using the International Plant Protection Convention (2002) definitions and include bacteria, fungi, insects, nematodes, mites, molluscs, phytoplasmas, viroids and viruses. These surveys were designed to provide a $95 \%$ probability of detecting such pests occurring at $\geq 1 \%$ of sites. This sampling regime normally required 50-250 plants to be sampled from more than 300 sites. After ten years of this effort, it was concluded that adequate baseline data had been obtained, and the surveys were stopped. It was also recognised that these surveys would not be adequate to detect pests in time for successful eradication. Some of the effort used for these surveys was redirected to evaluate the possibility of conducting active surveillance in order to detect other high impact exotic pests besides fruit flies in time to eradicate them. It was anticipated that this would not be practical for a number of serious pests, in which case exclusion would be New Zealand's best protection, together with ensuring full awareness of this by affected parties.

\section{High impact exotic plant pests and active surveillance}

Usually new organisms that are identified from public submissions and general surveillance are detected too late for eradication action to be feasible. Crop surveys were discontinued in preference for development of a more directed approach that targets selected high impact exotic plant pests (HIEP). MAF defines HIEPs as those pests with potential to cause major economic loss through lost production, reduced product quality or loss of export market access. The first challenge is to determine the priority HIEPs to target, an activity that should involve input from other interested parties besides MAF.

In the last two years the NPPRL at Lynfield and Lincoln have undertaken pilot surveys to determine the feasibility of conducting active surveillance on a range of selected HIEPs (Ganev \& Braithwaite 2003). These organisms were selected as potentially HIEPs and included a selection of arthropods, fungi, bacteria and viruses exhibiting a diverse 
range of biological features (Table 1). These studies considered biology, epidemiology, and diagnostic methods for each of these pests and estimated the resources required to conduct surveys to detect in time to eradicate. Key resource areas such as staff, equipment and technology, and finance to conduct active surveillance were identified.

TABLE 1: High impact exotic plant pests targeted for active surveillance studies.

\begin{tabular}{|c|c|c|}
\hline Pest & $\begin{array}{l}\text { Organism } \\
\text { Type }\end{array}$ & Host Range \\
\hline $\begin{array}{l}\text { Tetranychus kanzawai } \\
\text { Kanzawa mite }\end{array}$ & Mite & $\begin{array}{l}\text { Hydrangea, nashi, eggplant, } \\
\text { watermelon, beans, mulberry, } \\
\text { strawberry, etc. }\end{array}$ \\
\hline $\begin{array}{l}\text { Conogethes punctiferalis } \\
\text { Yellow peach moth }\end{array}$ & Insect & $\begin{array}{l}\text { Wide host range, including peaches, } \\
\text { sorghum, sunflowers, fruits and } \\
\text { maize }\end{array}$ \\
\hline Plum pox potyvirus & Virus & Stonefruit of genus Prunus \\
\hline $\begin{array}{l}\text { Xylella fastidiosa } \\
\text { Pierce's disease }\end{array}$ & Bacterium & Grapes \\
\hline $\begin{array}{l}\text { Homalodisca coagulata } \\
\text { Glassy winged sharpshooter (GWSS) }\end{array}$ & Insect & $\begin{array}{l}\text { Large host range includes many NZ } \\
\text { species. Vector for Pierce's disease. }\end{array}$ \\
\hline $\begin{array}{l}\text { Xanthomonas axonopodis pv. citri } \\
\text { Citrus Canker }\end{array}$ & Bacterium & Citrus \\
\hline $\begin{array}{l}\text { Tilletia indica } \\
\text { Karnal Bunt }\end{array}$ & Fungus & $\begin{array}{l}\text { Wheat, rye, triticale (i.e. wheat } x \\
\text { rye hybrids) }\end{array}$ \\
\hline $\begin{array}{l}\text { Puccinia asparagi } \\
\text { Asparagus rust }\end{array}$ & Fungus & Asparagus, chives, onions \\
\hline $\begin{array}{l}\text { Gymnosporangium asiaticum } \\
\text { Asian pear rust }\end{array}$ & Fungus & $\begin{array}{l}\text { Pears. Requires juniperus and } \\
\text { rosaceous hosts to complete life } \\
\text { cycle }\end{array}$ \\
\hline $\begin{array}{l}\text { Gymnosporangium juniperi- } \\
\text { virginianae } \\
\text { Apple rusts }\end{array}$ & Fungus & $\begin{array}{l}\text { Apples, junipers. Requires juniperus } \\
\text { and rosaceous hosts to complete life } \\
\text { cycle }\end{array}$ \\
\hline $\begin{array}{l}\text { Monilinia fructigena } \\
\text { Apple brown rot }\end{array}$ & Fungus & $\begin{array}{l}\text { Drupaceous and pomaceous species, } \\
\text { including apple, pear, quince, plum } \\
\text { and sweet cherry. }\end{array}$ \\
\hline
\end{tabular}

Figure 1 shows the estimated costs of high impact exotic plant pest surveillance. Estimated annual surveillance costs varied from relatively low for surveillance for three fungi of pipfruit $(\$ 280,000)$ to $\$ 1.1$ million for Pierce's disease and glassy-winged sharpshooter at the $99 \%$ level of detection. Costs for plum pox surveillance were estimated to be \$3.8 million and soil-borne wheat mosaic virus \$22.5 million at the $99 \%$ level of detection, but these two extreme values were not included in the graph for purposes of clarity. The combined cost of surveillance of these 12 selected HIEPs is estimated in excess of $\$ 31.5$ million annually for a $99 \%$ level of detection. These estimates also do not consider costs of backyard surveillance in high-risk areas such as Auckland.

The high cost of active surveillance for so few pests emphasises the need for MAF and other stakeholders, such as industry, to consider options for active surveillance and to develop approaches which demonstrate positive cost benefits in this context. The potential for effective active surveillance, other than for fruit fly, may be limited if MAF takes sole responsibility for these programmes, but this potential can be significantly enhanced by collaboration. There is also potential to exploit existing crop management practices and use these as a vehicle to conduct active surveillance, thus significantly reducing costs. MAF Plants Biosecurity are presently initiating discussions on surveillance 
options with industry through simulation workshops on specific pest incursions. MAF is looking to develop ways to increase the effectiveness of communication given the huge challenge presented by the diverse range of crops grown in agriculture and horticulture and the diverse industries based on these. This approach is consistent with recommendations in MAF's recent review of surveillance (Pearson 2002).

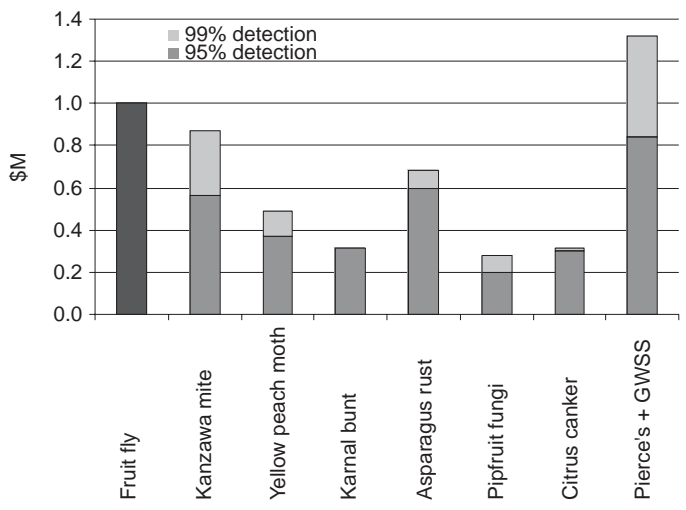

FIGURE 1: Estimated cost of high impact exotic plant pest surveillance, excluding plum pox and soil-borne wheat mosaic virus.

\section{Incursion response}

In spite of measures taken by MAF, incursions of exotic organisms are inevitable, given trade volumes, tourism and natural dispersal of new organisms. Uncontrolled pathways that may result in pest incursions include wind dispersal (rusts, aphids and Lepidoptera) and smuggling. When new organisms are detected, MAF's policy statement on responding to an exotic organism incursion (Anon 2001) requires the conduct of pest assessments, consultation with affected parties and formulation of follow-up actions. Consultation with affected parties is a recent specification and MAF is still determining procedures to provide appropriate communication in view of the biology of each organism and available resources. This means that many organisms considered to be of minor significance are simply published in MAF's Biosecurity magazine, which is available on MAF's website (http://www.maf.govt.nz/biosecurity/publications/biosecuritymagazine/index.htm). If fruit fly was to be detected in New Zealand, an eradication programme based on a pre-defined and well-documented procedurally-based response system would be implemented (Stephenson 1989). A measured response approach is taken for all other exotic pest incursions. This type of response involves the development and implementation of a strategy for pest containment and, if appropriate, eradication. MAF has developed its own standards for exotic pest and disease response in the absence of available FAO standards and operates these under the incursion policy (Anon 2001). MAF has started to enter into discussion with industry on application of this approach to specific high impact exotic pests and development of appropriate response contingencies. Issues and challenges for Plants Biosecurity

There are a number of issues that face MAF Biosecurity Authority both biologically and financially. At the biological level the Plants Biosecurity Index (http://www1.maf.govt.nz/ cgi-bin/bioindex/bioindex.pl) lists most of the plants known to exist in New Zealand, and suggests that there are approximately 25,000 plant species as potential hosts for exotic incursions. Import Health Standards, which contain pest lists by host derived from reviews of the world's literature, on average list 50 seed and 300 plant organisms per commodity of potential risk. The lists increase constantly with the identification of new organisms, and it 
is therefore necessary for MAF Biosecurity to prioritise areas for investment by assessing high impact exotic pests and minimising risks. Prioritising HIEPs will allow MAF and stakeholders to rationally consider the merits of conducting active surveillance and prepare contingency plans, which might allow rapid management and eradication in the event that these organisms enter New Zealand.

\section{ACKNOWLEDGEMENTS}

We thank the staff of the National Plant Pest Reference Laboratory for conducting research on active surveillance programmes.

\section{REFERENCES}

Anon. 2001: Policy statement on responding to an exotic organism incursion. MAF Biosecurity Authority, Wellington. August 2001.

Cowley, J. M. 1990: A new system of fruit fly surveillance trapping in New Zealand. The N.Z Entomol. 13: 81-84.

Frampton, E.R. 2000: An overview of quarantine for fruit flies. In: Area-Wide Control of Fruit Flies and Other Insect Pests. Tan, K.-H. ed. International Atomic Energy Agency, Perpustakaan Negara, Malaysia. Pp. 475-479.

Ganev, S.; Braithwaite, M. 2003: Resource requirements for national active surveillance programmes of high impact exotic pests in New Zealand. N.Z Plant Prot. 56: 10-15.

Holder, P.W.; Stephenson, B.; Chadfield, K.; Frampton, R. 1997: The finding of Mediterranean fruit fly in Auckland, New Zealand and the Ministry of Agriculture's response. Weta. 20(1): 4-6.

International Plant Protection Convention 2002: Glossary of Phytosanitary Terms. International Standards for Phytosanitary Measures. Publication No. 5. (http://193.43.36.94/servlet /

CDSServlet?status=ND0xMzM5OSY3PWVuJjYxPXB1YmxpY2F0aW9ucyY2NT1rb3M )

Pearson, A.B. 2002: Review of New Zealand's Biosecurity Surveillance Systems. Prime Consulting International Ltd, Waikanae. Pp. 84-95.

Stephenson, B.P. 1989: Procedures for fruit fly (Tephritidae) eradication in New Zealand. Proc. 42nd N.Z. Weed and Pest Control Conf: 204-208. 